Original Research

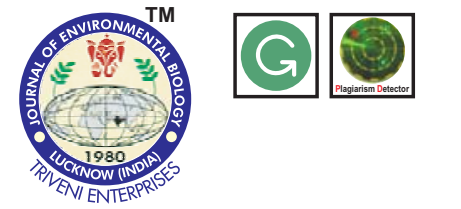

DOI : http://doi.org/10.22438/jeb/38/6/MRN-448

\title{
Distribution characteristics of heavy metals in flood plains, farm fields and high lands in Lake Poyang region in China
}

ISSN: 0254-8704 (Print)

ISSN: 2394-0379 (Online) CODEN: JEBIDP

\section{Authors Info \\ Y. Ji ${ }^{1 *}$, J. Zhang ${ }^{1,2}$, C. Bai ${ }^{1,3}$, W. Zhu', G. Cai', L. Hu' and G. Gao ${ }^{1,4}$}

${ }^{1}$ School of Water Conservancy and Ecological Engineering, Nanchang Institute of Technology, Nanchang, 330 099, China

${ }^{2}$ College of Environmental, Hohai University, Nanjing 210 098, China

${ }^{3}$ Key Laboratory of Water Science and Engineering, Nanjing Hydraulic Research Institute, Nanjing, 210 029, China

${ }^{4}$ Water Resource and Eco-system Environmental Research Center for Poyang Lake, Ministry of water resources, Nanchang, 330029 , China

*Corresponding Author Email : jiyong@nit.edu.cn

Key words

Flood plains

Heavy metals

Lake Poyang

Mining activities

Rice fields

Publication Info

Paper received : 02.09.2016

Revised received : 14.12 .2016

Re-revised received : 20.03.2017

Accepted: 17.05.2017

\section{Abstract}

Aim : Rice plantations have greatly contributed to the population and economic growth of Lake Poyang Basin, where heavy metal contamination has become increasingly serious due to considerable non ferrous metal mining and processing enterprises. Based on the values of heavy metals of soils sampled from the Le'An River Basin area, the present study aimed to investigate the pollutants distribution characteristics in flood plains, farmlands and rice fields, identify the potential sources and assess the ecological risk.

Methodology : After a full survey in the midstream area of the Le'An River, twentynine sampling stations were selected from the flood plains, farmlands and high lands, and analyzed using a sequential chemical extraction method. Sediment quality values, pollution indexes and geoaccumulation indexes were combined with statistical analyses and were performed to evaluate the spatial characteristics of heavy metals, assess the ecosystem risks and identify the potential sources.

Results : There was a clear spatial Evalnating the effect of mining activities distribution characteristic with a significant increasing trend from the high lands to the flood plains, where heavy metal concentrations were significantly higher than the corresponding background values, such as the levels of $\mathrm{Cd}$ and $\mathrm{Cu}$ at Station 6 and Station 18, respectively. Furthermore, the ratio of bioavailability metal chemical partition was over $50 \%$ of the total metals. Various assessments that employed different methods indicated that the degree of contamination in the flood plains was extreme, whereas the pollution in the rice plant fields was lower than that in the flood

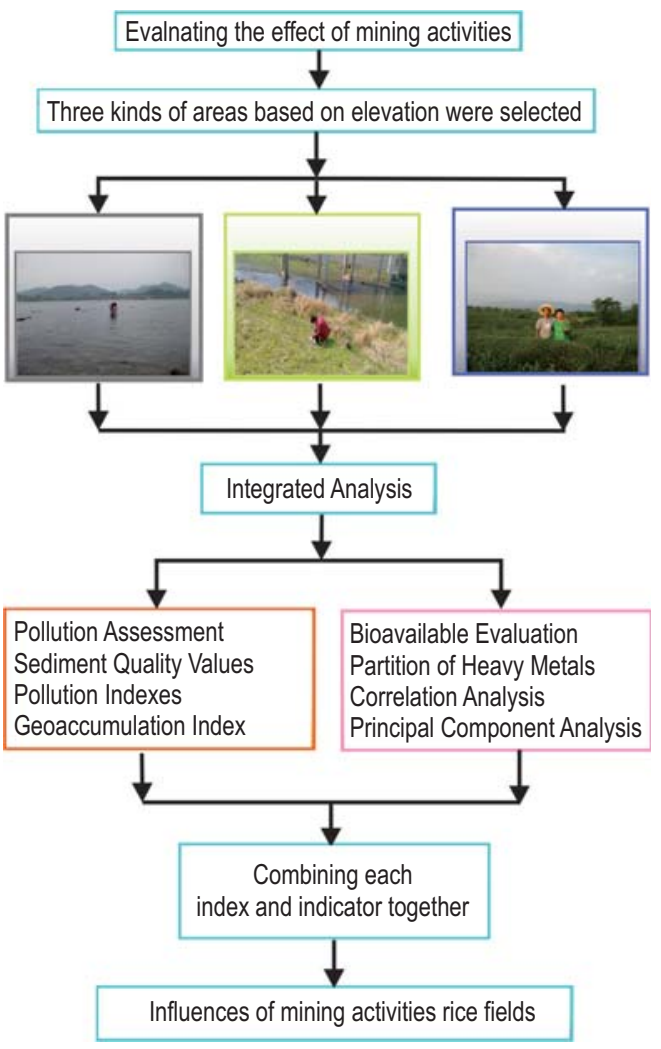
plains. Two sources of pollutants were revealed through statistical analysis, one that was explained by the mixed origin of industrial emissions and one that was related to terrigenous components.

Interpretation : Anthropogenic activities such as domestic runoffs, mining processes, irrigation and petroleum industries may significantly contribute to the distribution of heavy metals. 


\section{Introduction}

It is well acknowledged that heavy metals are the most important elements for life ecosystems and development of our present society. However, heavy metals are non-biodegradable and non-thermo degradable and they persist and accumulate in environmental ecosystems to toxic levels after extended period of time (Ajasa et al., 2004; Arora et al., 2008; Naimo, 1995). In recent years, heavy metal pollution of soil has attracted extensive attention due to serious negative effects on human health and on the environment (Muchuweti et al., 2006). A complete understanding of the availability and occurrence of heavy metals is critical to guarantee the quality of food and water (Christophoridis et al., 2009; Facchinelli et al., 2001). In fact, heavy metals may come from different sources, including transportation, agriculture, industrial discharges and human activities (Chander et al., 2001).

As a result of current and past metal mining, these activities have contaminated most river channels and flood plains in many parts of developed (Borrego et al., 2002) and developing countries (Ji et al., 2015; Razo et al., 2004). Heavy metals can deposit in soil at toxic levels due to long-term irrigation that uses wastewater produced from industry activities (Muchuweti et al., 2006; Arora et al., 2008). However, these elements can be released into the water body or soil solutions again when the outer environment transfers from one stage to another stage, and those then can be absorbed by farm vegetations (Muchuweti et al., 2006). Heavy metals in soil can also impact crop production, aquatic system health, and human health via food chains (Ajasa et al., 2004; Zhuang et al., 2009). Crops planted in neighbourhood of contaminated sites can slowly uptake and accumulate heavy metals, and thus eventually pose a potential risk to animals and humans (Muchuweti et al., 2006; Zhuang etal., 2009).

China, with a long history of rice agriculture, is the largest rice producer in the world. Thus, changes in rice production and quality will significantly impact food security not only in Asia, but throughout the world. Due to serious contamination of heavy metal in China (Bai et al., 2011; Deng et al., 2004; Li et al., 2014; Xin et al., 2014), agricultural soils have become a growing public concern ever (Alfaraas et al., 2016). However, few studies have been reported about the heavy metals distribution in rice planting areas. Lake Poyang is known widely in the world for its wetland and the largest freshwater lake in China. Pollutants in this region have attracted the attention of scientific community in recent years (Ji et al., 2014; Luo et al., 2008; Yuan et al., 2011). The Le'An River Basin (LRB), which attracts numerous nonferrous metal mining and processing companies, is situated in the eastern part of the Lake Poyang Basin, China (Fig. 1). These industrial activities have led to serious heavy metal accumulation (He et al., 1997; 1998). However, few reports have been reported about the spatial characteristics of heavy metals in these farmland areas. The present study aims to investigate the distribution of heavy metals elements in the flood plains, farm fields and high lands. Furthermore, this study also aims to assess the potential risk by using the pollution integrated index (PI) and geoaccumulation index $\left(I_{g e 0}\right)$, and to identify the potential sources of the studied heavy metals with respect to different sampling sites.

\section{Materials and Methods}

Study Sites : The rice fields are usually distributed along the banks of the main part of Le'An River, which is congested with numerous rural villages (Table 1). Nine major rice planting sites, namely, Daicun, Minkou, Houbu, Yanghu, Zhangjiazhou, Lucibu, Chengxin, Yejia and Shanglian were selected. Rice plants in these areas are usually grown from March to September. Waste water from the Dexing copper mine flows directly into the Dawu River and then runs into the main stream. The Jishui River is heavily polluted with metals and connects with the Le'An River at Daicun (Fig. 1, ST1). The main stream from ST17 to ST22 consists of numerous dredges and township enterprises that have no waste water disposal process.

Sample collection and preparation : The samples were collected from the flood plains, farm fields and high lands from 20 to 25 during March, 2014 (Fig. 1). To reduce the impact of soil heterogeneity, a five-point sampling method with a "W" type distribution was used to collect soil samples. After thorough mixing, every sample consisted of approximately $1 \mathrm{~kg}$ of surface lay sediment $(0$ to $20 \mathrm{~cm})$. The location of each sampling site was recorded using a global positioning system device (Magellan 310 GPS). A total of 145 samples were collected from 29 studied sites. With respect to the samples, 55 were collected from sites located in the flood plains, 55 were collected form farm fields and 35 were obtained from locations in the high lands. In laboratory, the samples were air dried at room temperature, crushed, grounded and then stored in refrigerator before analysis.

Sample analysis : Samples were microwave-digested for the analysis of total concentration analysis (MLS-1200 MEGA highperformance microwave digestion). Each digestion batch included a reagent blank and a representative reference standard. Chemical partitioning of $\mathrm{Cu}, \mathrm{Zn}, \mathrm{Pb}, \mathrm{Cd}, \mathrm{Cr}$ and $\mathrm{As}$ were analyzed by a sequential extraction method (Tessier et al., 1979) and the total concentration of heavy metals were determined by inductively coupled plasma-atomic emission spectrometry (ICP-AES, Thermo 6300). Reference materials, GSD-9 and GSD-11 offered by the Chinese Academy of Geological Sciences, were used to guarantee the accuracy of analysis. The coefficient of variation of replicate analysis was found to be less than $6 \%$, and the regression coefficient of calibration standards was $>0.999$. The certified values of repeated analysis of standards were within $\pm 2 \%$.

\section{Pollution Assessment}

Sediment quality values : Sediment quality values (SQVs) were used for the interpretation of sediment quality. As indicated in Table 2, the screening quick reference table (SQUIT) is designed to evaluate the pollution degree of heavy metals. Usually, the reference values in the SQUIT are divided into five levels based 


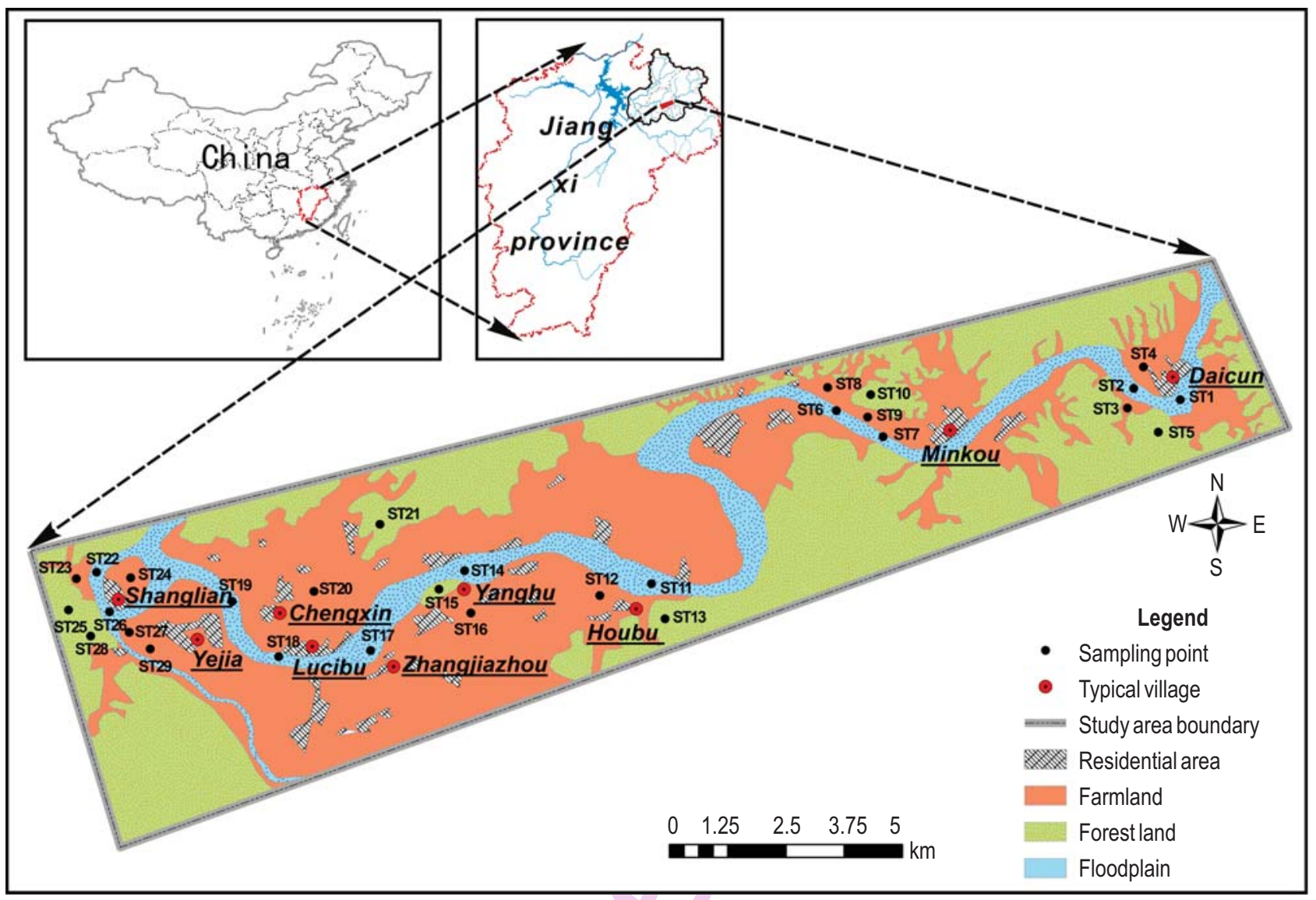

Fig. 1: Location of sampling sites ST1-ST29 in Lake Poyang, Jiangxi Province, China

on the observed effects, which are derived using several different laboratory methods.

Pollution Index : The pollution degree of heavy metals is evaluated by calculating the pollution index (PI) and Nemero synthesis index (integrated pollution indexes, NSI). In general, PI is calculated by dividing concentration with the geometric background concentration. As indicated in the reference, the Nemero synthesis index (NSI) can be calculated by the equation presented in the reference.

Geoaccumulation index : The geoaccumulation index $\left(I_{g e 0}\right)$ is a useful criterion for evaluating the pollution degree of heavy metals. Since publicly reported in the late $1960 \mathrm{~s}, I_{g e 0}$ has been widely introduced to assess the pollution degree of contaminated sediments in marine, aquatic and terrestrial environments, and has also been widely used for the assessment of soil pollution.

Statistical analysis : The IBM SPSS 19 was performed for all data analyses, and the statistical significance level was $\mathrm{P}<0.05$. The pollution indices were performed by the Excel 2003, and the potential sources of heavy metals were distinguished by correlation analysis and principal component analysis (PCA) method. ArcGIS10.0 was performed to analyze the spatial distribution location of sampling sites.

\section{Results and Discussion}

The distribution of heavy metals for 29 sampling sites collected from nine typical rural villages is presented in Fig. 2 and Table 3. Generally, the flood plains exhibited the highest values of all heavy metals due to the continuous source contamination from upstream, where many non ferrous metal mining and processing companies, including the Dexing Copper Company, were distributed along the Le'An River. Spatial distribution of heavy metal in the rice fields is similar to those of the main river. As usual the intermittent use of irrigation water directly from the main river has led to the accumulation of heavy metals in the farm soils. The values of heavy metals in high lands are less than the values of those collected from rice fields and flood plains.

The maximum values were usually detected in the mud flats close to mining industries, such as ST6 and ST7, which were close to industry parks, and ST14, ST17, ST18 and ST19 which were affected by dredges and township enterprises. With respect to absolute concentration, the highest mean concentrations were recorded for $\mathrm{Zn}$ atall sites, followed by $\mathrm{Cu}, \mathrm{Pb}, \mathrm{Cr}$ and As. ST6, which was close to Minkou village, recorded the highest concentrations of $\mathrm{Zn}, \mathrm{Cd}$ and $\mathrm{Cr}$. The results indicate that the significant spatial variability is mainly contributed by the variations of heavy metal 
Table 1 : Location, description of activities and sample type

\begin{tabular}{|c|c|}
\hline Sampling sites & Activity/Establishment \\
\hline $\begin{array}{l}\text { Part I (ST1, ST2, } \\
\text { ST6, ST7, ST11, } \\
\text { ST14, ST17, ST18, } \\
\text { ST19, ST22, ST26) }\end{array}$ & $\begin{array}{l}\text { All sampling sites are located in the floodplain in main channel which are bare in dry season and are flooded in raining } \\
\text { season with polluted water coming from the upstream of Dexing copper mine, Yinshan Lead Zinc Mine and other heavy } \\
\text { metal mining production. Generally, sediments collected from these areas are mainly constituted of sand and clay. Among of } \\
\text { them, ST6 and ST7 are close to industry parks where there are hundreds of enterprises without any wastewater treatment } \\
\text { process. With the steady and slow flow, the main rivers from ST17 to ST22 are full of dredges through the whole year and } \\
\text { township enterprises without any wastewater disposal process. Usually, the rice plants are distributed along the banks of the } \\
\text { main Le'An River congested with numerous rural villages. }\end{array}$ \\
\hline $\begin{array}{l}\text { Part II (ST3, ST4, } \\
\text { ST8, ST9, ST12, } \\
\text { ST16, ST20, ST23, } \\
\text { ST24, ST27, ST29) }\end{array}$ & $\begin{array}{l}\text { In general, sampling sites in these areas are located in rice fields close to the main river from where polluted water has been } \\
\text { taken and used directly to irrigate farms for many years. Among of them, ST4 and ST20 are overly close to residential areas } \\
\text { and the rural roads. ST8 is close to country road. Local downtown and middle school are located neighbor to ST9. Interstate } \\
\text { Lejiang highway pass through ST23 and ST29, while ST24 and ST26 are surrounded by river and local residential villages. }\end{array}$ \\
\hline $\begin{array}{l}\text { Part III (ST5, ST10, } \\
\text { ST13, ST15, ST21, } \\
\text { ST25, ST28) }\end{array}$ & $\begin{array}{l}\text { These samples sites assorted in this part are referred to minor polluted areas. In general, samplings are collected from } \\
\text { natural woodlands in highlands far from agriculture and industry disturbance. Usually, there are not flourish industries, } \\
\text { mining enterprises and chemical companies in these areas. }\end{array}$ \\
\hline
\end{tabular}

Table 2 : Screening Quick Reference Table (SQUIT) for heavy metals in marine sediment $\left(\mu g^{-1}\right)$

\begin{tabular}{llllll}
\hline & TEL & ERL & PEL & ERM & AET \\
\hline $\mathrm{Cu}$ & 18.70 & 34.00 & 108.00 & 270.00 & $390.00(\mathrm{MO})$ \\
$\mathrm{Zn}$ & 124.00 & 150.00 & 271.00 & 410.00 & $410.00(\mathrm{I})$ \\
$\mathrm{Pb}$ & 30.24 & 46.70 & 112.00 & 218.00 & $400.00(\mathrm{~B})$ \\
$\mathrm{Cd}$ & 0.68 & 1.20 & 4.21 & 9.60 & $3.00(\mathrm{~N})$ \\
$\mathrm{Cr}$ & 52.30 & 81.00 & 160.00 & 370.00 & $62.00(\mathrm{~N})$ \\
$\mathrm{As}$ & 7.24 & 8.20 & 41.60 & 70.00 & $35.00(\mathrm{~B})$ \\
\hline
\end{tabular}

Bioassay endpoints: M - Microtos; O - Oyster larvae; I - Infaunal community impacts; B - Bivalve; N - Neanthes; E- Echinoderm larvae; L - Larval bioassay

Table 3 : Concentrations of heavy metals $\left(\mathrm{mg} \cdot \mathrm{g}^{-1}\right.$ dry wt.) in sediments collected from sampling sites

\begin{tabular}{|c|c|c|c|c|c|c|}
\hline \multirow[b]{2}{*}{ Sites } & \multicolumn{6}{|c|}{ (mg $\cdot g^{-1}$ dry wt.) } \\
\hline & $\mathrm{Cu}$ & $\mathrm{Zn}$ & $\mathrm{Pb}$ & $\mathrm{Cd}$ & $\mathrm{Cr}$ & As \\
\hline Max & 2699.63 & 3500.48 & 1242.73 & 75.73 & 369.01 & 271.32 \\
\hline Min & 562.06 & 1796.05 & 647.99 & 21.74 & 168.68 & 59.10 \\
\hline Mean & 1971.03 & 2857.41 & 1025.52 & 44.91 & 291.47 & 174.25 \\
\hline \multicolumn{7}{|c|}{ Part I: All sampling sites are collected on floodplains in the main channel. } \\
\hline Max & 818.90 & 2927.75 & 997.27 & 37.50 & 380.61 & 88.01 \\
\hline Min & 312.83 & 1073.00 & 365.88 & 8.82 & 108.26 & 32.61 \\
\hline Mean & 510.71 & 1837.53 & 612.87 & 18.93 & 227.13 & 53.48 \\
\hline \multicolumn{7}{|c|}{ Part II: Sampling sites are located in rice farmland close to the main river. } \\
\hline Max & 37.27 & 77.48 & 32.25 & 3.06 & 69.36 & 17.51 \\
\hline Min & 23.02 & 67.48 & 25.86 & 1.40 & 54.97 & 7.51 \\
\hline Mean & 31.42 & 73.44 & 29.61 & 2.18 & 62.42 & 13.21 \\
\hline \multicolumn{7}{|c|}{ Part III: This part is collected in highlands which are far from human activities. } \\
\hline Background ${ }^{*}$ & 35.37 & 73.91 & 39.41 & 0.75 & 50.54 & 12.84 \\
\hline
\end{tabular}

*Background values of heavy metals in Poyang Lake (Gong et al., 2006)

sources and the quantity of pollutants discharged through the sewage and effluents of the main river (Ni et al., 2011). However, the high lands have values similar to those of Lake Poyang, which may be due to less effluence from the social activities.
After comparing the background values in Lake Poyang (Gong et al., 2006), the results reveal that the main stream of River Le'an is facing threat due to the heavy metals. This is especially true for $\mathrm{Cd}$ and $\mathrm{Cu}$, whose levels were 59.88 and 55.73 times 
higher than their corresponding background values. Even the $\mathrm{Cr}$ values were 5.77 times higher than their corresponding background values. The measured elements showed an increasing order for enrichment as : $\mathrm{Cr}<\mathrm{As}<\mathrm{Pb}<\mathrm{Zn}<\mathrm{Cu}<\mathrm{Cd}$. Compared with the levels of heavy metals in the flood plains, a similar trend can be concluded for the pollution degree in the rice fields, where $\mathrm{Cd}$ was 25.24 times higher than their background values. However, no serious pollution was detected in the high lands when compared with the background values. After comparing the data presented in Table 4, it can be concluded that the degree of pollution in flood plains was significantly higher than that rice farmlands (Part II) irrigated with polluted river water that exhibited relatively higher degrees of severe pollution (Liu et al.,
2002; Zhang et al., 2009). It is further noted that the results of the present study exceeded the data reported in the same region of Raohe (Zeng etal., 2011).

The geochemical conditions existing in the sediment can significantly affect the heavy metals envionmental activities (Kokovides et al., 1992; Adamo et al., 2005). As presented in Table 5 and Fig. 3 , the partitioned fractions from 1 to 3 , named as percentage of the potential bioavailability for $\mathrm{Cu}, \mathrm{Zn}, \mathrm{Pb}, \mathrm{Cd}$ and $\mathrm{Cr}$, exceeded $50 \%$ of the total metals. In general, the percentage of bioavailability for $\mathrm{Zn}, \mathrm{Cd}, \mathrm{Cr}$ and $\mathrm{As}$ in the high lands were slightly higher than for other elements. The highest potential bioavailability value for $\mathrm{Cu}$ was recorded in the flood plains.
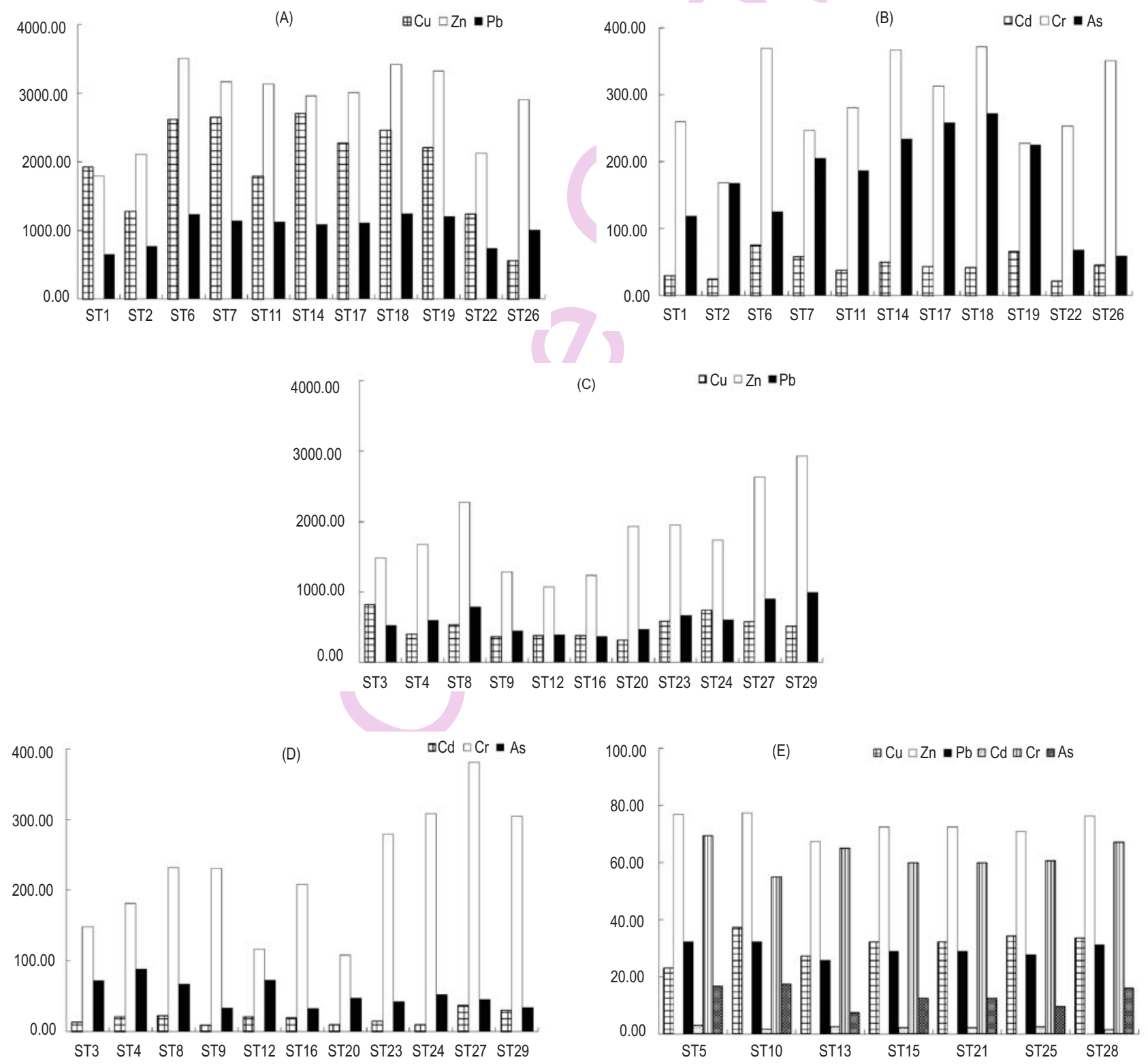

Fig. 2 : Distribution of heavy metals in floodplains ( $A$ and $B)$, farm fields $(C$ and $D)$ and highlands $(E)$ 
Table 4 : Comparison of heavy metal concentrations in study area with those in other regions $\left(\mathrm{mgkg}^{-1}\right)$

\begin{tabular}{|c|c|c|c|c|c|c|c|}
\hline \multirow[t]{2}{*}{ Location } & \multicolumn{7}{|c|}{ Metal concentration (mg/kg) } \\
\hline & $\mathrm{Cu}$ & $\mathrm{Zn}$ & $\mathrm{Pb}$ & $\mathrm{Cd}$ & $\mathrm{Cr}$ & As & Reference \\
\hline Main channel of Part I & 1971.03 & 2857.41 & 1025.52 & 44.91 & 291.47 & 174.25 & This study \\
\hline Rice farmland of Part II & 510.71 & 1837.53 & 612.87 & 18.93 & 227.13 & 53.48 & This study \\
\hline Woodland of Part III & 31.42 & 73.44 & 29.61 & 2.18 & 62.42 & 13.21 & This study \\
\hline Roahe Estuary, China & 150.13 & 221.85 & 115.19 & na & na & na & Zeng et al., 2011 \\
\hline Xinjiang, China & 100.11 & 217.08 & 53.79 & 4.32 & na & na & Li et al., 2008 \\
\hline Nanjishang Reserve, China & 45.59 & 105.6 & 103.4 & 0.413 & na & na & Gong et al., 2006 \\
\hline Zhujiang River, China & 39.02 & 110.85 & 59.43 & 0.34 & 56.40 & 5.24 & Liu et al., 2002 \\
\hline Changjiang River, China & 30.70 & 94.30 & 27.30 & 0.26 & 78.90 & na & Zhang et al., 2009 \\
\hline Yangtze River, China & 44.24 & 107.68 & 29.77 & 0.48 & 74.88 & 33.92 & Yi et al., 2011 \\
\hline Mahanadi basin, India & 36.00 & 137.00 & 130.90 & 4.30 & 72.10 & $\mathrm{Na}$ & Sundarary et al., 2011 \\
\hline Danube Delta, Romanian & 65.70 & 187.00 & 46.30 & 1.20 & 64.00 & 17.60 & Woitka et al., 2003 \\
\hline
\end{tabular}

Table 5 : Partitioning of metals in rice plant field (Poyang Lake Region, China, $\mathrm{mgkg}^{-1}$ )

\begin{tabular}{|c|c|c|c|c|c|c|c|}
\hline & & $\mathrm{Cu}$ & $\mathrm{Zn}$ & $\mathrm{Pb}$ & $\mathrm{Cd}$ & $\mathrm{Cr}$ & As \\
\hline \multirow[t]{4}{*}{ Part I } & B1 & 358.95 & 584.00 & 111.12 & 12.33 & 13.84 & 20.06 \\
\hline & B2 & 634.20 & 506.42 & 370.62 & 16.96 & 98.46 & 18.74 \\
\hline & B3 & 276.04 & 750.16 & 161.18 & 1.96 & 28.08 & 14.38 \\
\hline & B4 & 701.84 & 1016.83 & 382.60 & 13.66 & 151.10 & 121.07 \\
\hline \multirow[t]{4}{*}{ Part II } & B1 & 36.68 & 94.12 & 31.21 & 1.60 & 6.37 & 6.35 \\
\hline & B2 & 97.91 & 163.56 & 238.75 & 9.78 & 78.40 & 7.70 \\
\hline & B3 & 120.57 & 498.43 & 160.05 & 1.97 & 34.57 & 5.96 \\
\hline & B4 & 255.55 & 1081.42 & 182.87 & 5.58 & 107.78 & 33.48 \\
\hline \multirow[t]{4}{*}{ Part III } & B1 & 5.62 & 27.26 & 8.66 & 0.44 & 3.55 & 0.82 \\
\hline & B2 & 4.94 & 18.55 & 2.44 & 0.55 & 26.62 & 1.59 \\
\hline & B3 & 6.65 & 9.75 & 1.86 & 0.68 & 7.74 & 2.86 \\
\hline & B4 & 14.21 & 17.89 & 16.65 & 0.52 & 24.52 & 7.94 \\
\hline
\end{tabular}

The correlation matrix of six Part I heavy metals is presented in Table 6 . The results indicate that the acid extractable fractions positively correlated well with each other. Excluding the correlation between $\mathrm{Cr}$ and $\mathrm{As}$, a similar positive correlation can also be concluded for the reducible fraction. Table 6 also indicates that the reducible fraction for $\mathrm{Cu}$ almost correlates well with all other reducible fractions. However, the oxidizable fractions for heavy metals did not exhibit good positive relationships with each other. In general, heavy metals in the flood plains revealed positive correlations and currently may arise from the same sources. Some reports indicate that the discharges from Dexing copper mine and the mines along the Le'An River have resulted in a significant accumulation of heavy metals (He et al., 1997; 1998). The results of the correlation matrix of Part II are presented in Table 7. It is not surprising that most heavy metals in this part did not exhibit positive correlations with each other. The $r$ values were commonly at low levels in all fractions. The results indicate that the source of heavy metals in Part II is complicated and affected by various activities. Polluted irrigation water is one of the important sources for heavy metals. Furthermore, the current irrigation methods have also drained the surrounding area and contributed to the contamination of the sediments (Liu et al., 1999).

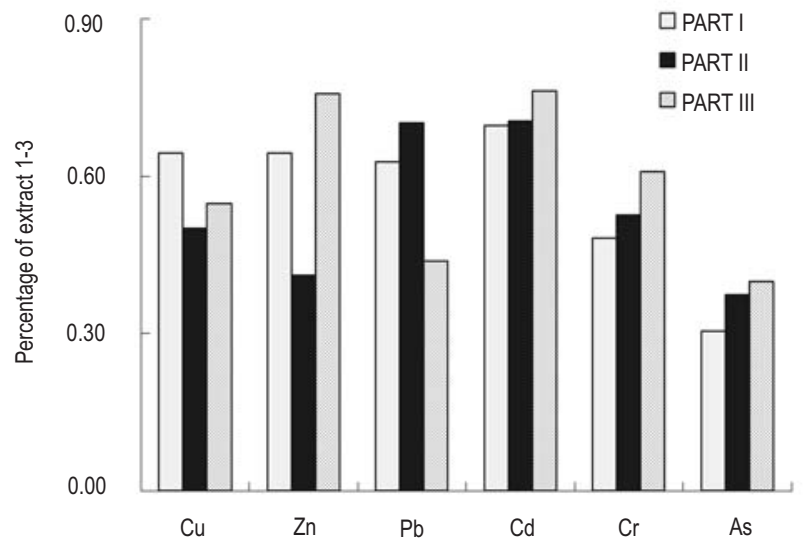

Fig. 3 : Metals extracted from fractions 1-3 as a percentage of total metal concentration.

In most cases, the sediment quality criteria (SQC) are used to promote additional biological and chemical testing to determine the extent and significance of the contamination (Burton, 2002; Waykar and Petare, 2016). In the present study, 
Table 6 : Significant correlations between any two heavy metal binding fractions (PART I)

\begin{tabular}{|c|c|c|c|c|c|c|}
\hline & $\mathrm{Cu}$ & $\mathrm{Zn}$ & $\mathrm{Pb}$ & $\mathrm{Cd}$ & $\mathrm{Cr}$ & As \\
\hline \multicolumn{7}{|l|}{ (1) } \\
\hline $\mathrm{Cu}$ & 1.00 & & & & & \\
\hline $\mathrm{Zn}$ & 0.474 & 1.00 & & & & \\
\hline $\mathrm{Pb}$ & 0.321 & $0.846^{* *}$ & 1.00 & & & \\
\hline $\mathrm{Cd}$ & $0.663^{*}$ & 0.371 & 0.185 & 1.00 & & \\
\hline $\mathrm{Cr}$ & 0.293 & 0.416 & $0.688^{*}$ & 0.109 & 1.00 & \\
\hline As & 0.327 & 0.575 & 0.598 & 0.335 & $0.664^{*}$ & 1.00 \\
\hline \multicolumn{7}{|l|}{ (2) } \\
\hline $\mathrm{Cu}$ & 1.00 & & & & & \\
\hline $\mathrm{Zn}$ & $0.730^{*}$ & 1.00 & & & & \\
\hline $\mathrm{Pb}$ & $0.690^{*}$ & $0.883^{* *}$ & 1.00 & & & \\
\hline $\mathrm{Cd}$ & $0.658^{*}$ & $0.790^{* *}$ & $0.701^{*}$ & 1.00 & & \\
\hline $\mathrm{Cr}$ & $0.624^{*}$ & $0.905^{\star *}$ & $0.749^{\star *}$ & $0.705^{\star}$ & 1.00 & \\
\hline As & 0.086 & 0.146 & 0.349 & 0.152 & -0.145 & 1.00 \\
\hline \multicolumn{7}{|l|}{ (3) } \\
\hline $\mathrm{Cu}$ & 1.00 & & & & & \\
\hline $\mathrm{Zn}$ & 0.176 & 1.00 & & & & \\
\hline $\mathrm{Pb}$ & 0.071 & $0.691^{*}$ & 1.00 & & & \\
\hline $\mathrm{Cd}$ & 0.282 & 0.110 & 0.064 & 1.00 & & \\
\hline $\mathrm{Cr}$ & $-0.801^{* *}$ & -0.028 & -0.052 & $-0.650^{*}$ & 1.00 & \\
\hline As & $0.811^{* *}$ & 0.638 & 0.345 & 0.197 & -0.499 & 1.00 \\
\hline
\end{tabular}

(1) Acid extractable fraction, (2) Reducible fraction, (3) Oxidizable fraction. Significant values $(p<0.05)$ are marked with an asterisk $\left(^{*}\right)$; Significant values $(p<0.01)$ are marked with double asterisks $\left.{ }^{* *}\right)$

Table 7 : Significant correlations between any two heavy metal binding fractions (PART II)

\begin{tabular}{|c|c|c|c|c|c|c|}
\hline & $\mathrm{Cu}$ & $\mathrm{Zn}$ & $\mathrm{Pb}$ & $\mathrm{Cd}$ & $\mathrm{Cr}$ & As \\
\hline \multicolumn{7}{|l|}{ (1) } \\
\hline $\mathrm{Cu}$ & 1.00 & & & & & \\
\hline $\mathrm{Zn}$ & 0.328 & 1.00 & + & & & \\
\hline $\mathrm{Pb}$ & 0.474 & 0.122 & 1.00 & & & \\
\hline $\mathrm{Cd}$ & $0.830^{* *}$ & -0.035 & 0.497 & 1.00 & & \\
\hline $\mathrm{Cr}$ & 0.260 & -0.452 & -0.008 & 0.404 & 1.00 & \\
\hline As & 0.573 & 0.419 & 0.055 & 0.393 & -0.279 & 1.00 \\
\hline \multicolumn{7}{|l|}{ (2) } \\
\hline$\overline{\mathrm{Cu}}$ & 1.00 & & & & & \\
\hline $\mathrm{Zn}$ & -0.125 & 1.00 & & & & \\
\hline $\mathrm{Pb}$ & 0.292 & 0.239 & 1.00 & & & \\
\hline $\mathrm{Cd}$ & 0.164 & -0.105 & -0.162 & 1.00 & & \\
\hline $\mathrm{Cr}$ & 0.063 & -0.166 & 0.357 & 0.315 & 1.00 & \\
\hline As & 0.172 & -0.319 & -0.132 & 0.253 & -0.147 & 1.00 \\
\hline \multicolumn{7}{|l|}{ (3) } \\
\hline $\mathrm{Cu}$ & 1.00 & & & & & \\
\hline $\mathrm{Zn}$ & 0.104 & 1.00 & & & & \\
\hline $\mathrm{Pb}$ & 0.449 & -0.006 & 1.00 & & & \\
\hline $\mathrm{Cd}$ & 0.217 & -0.043 & 0.474 & 1.00 & & \\
\hline $\mathrm{Cr}$ & -0.493 & 0.098 & 0.059 & 0.542 & 1.00 & \\
\hline As & $0.918^{* *}$ & 0.140 & 0.297 & -0.020 & -0.561 & 1.00 \\
\hline
\end{tabular}

(1) Acid extractable fraction, (2) Reducible fraction, (3) Oxidizable fraction. Significant values $(p<0.05)$ are marked with an asterisk (*); Significant values $(p<0.01)$ are marked with double asterisks $\left(^{* *}\right)$ 
the marine SQV was used for evaluation of sediment heavy metals. As shown in Table 5, all the heavy metals in Part I were above ERM and AET, except for $\mathrm{Cr}$ with concentrations of 291.47 for total metals above PEL and 140.37 for bioavailability partitioned fractions above ERL. By comparing the maximum values to SQUIT guidelines, the values of $\mathrm{Cu}, \mathrm{Zn}, \mathrm{Pb}, \mathrm{Cd}$ and $\mathrm{As}$ in Part II were above ERM, while that of $\mathrm{Cr}$ was slightly above PEL. The bioavailable portion of $\mathrm{Zn}, \mathrm{Pb}$ and $\mathrm{Cd}$ in Part II was above ERM posing adverse effects on aquatic organisms. Meanwhile, the concentrations of bioavailable portion of Cu were above PEL and those of $\mathrm{Cr}$ and As were above ERL. However, the bioavailable portion of heavy metals in Part III was almost lower the PEL, indicating that Part III remains relatively clear.

The calculations of pollution index $(\mathrm{PI})$ and Nemero synthesis index (NSI) are listed in Table 8. Based on the PI values, sediments in Part I had the highest contamination level, with a value 3.0. The minimum value was 3.34 for $\mathrm{Cr}$. It can be concluded that the flood plains have been heavily contaminated in the past decades. In Part I, the degree of heavy metal pollution increased in the following order : $\mathrm{Cr}<\mathrm{As}<\mathrm{Pb}<\mathrm{Zn}<\mathrm{Cu}<\mathrm{Cd}$ Similarities were also found in Part II, most elements exceeded the highest contamination level, excluding As and $\mathrm{Cr}$. However, $\mathrm{Cu}, \mathrm{Zn}, \mathrm{Cr}, \mathrm{Pb}$ and $\mathrm{As}$ in Part III approached the background values. The NSI values were also calculated for each sample and presented in Table 8. The significant differences for the NSI values between different parts are recorded, which is likely due to different pollution sources and local background variations. Compared with the Soil Environmental Quality Assessment
Standards (State Development Center for Green-food of China 2000), sampling areas in Part I and Part II can be sorted as highly contaminated, and that in Part III can be sorted as less contaminated.

As presented in Table 9, the $I_{\text {geo }}$ was performed to evaluate the contamination of heavy metals. In general, the $I_{\text {geo }}$ values for Parts I, II, and III reveal obvious differences. Applying the classification system devised by Müller, the elements range from uncontaminated (Class 0 ) to extremely contaminated (Class 6). Apart from $\mathrm{Cr}$, the $I_{\text {geo }}$ values in Part I reveal that nearly all the examined elements fall into Classes 5 and 6 indicating extreme contamination in these areas. The $I_{g e 0}$ value for Cr in Part I was 1.90, indicating that the sediment in this sampling area is moderately contaminated. The $I_{g e o}$ values for As in Part I were greater than three. The $I_{g e 0}$ values in Part ll for Cu, Zn were lower than those in Part I with two class differences. According to the $I_{\text {geo }}$ values in Part II, sediments in most of the sampling areas in this section could be classified as moderately to heavily contaminated. In Part III, the $I_{\text {geo }}$ values for most elements were lower than 0 , with the exception of $\mathrm{Cd}$, which falls into the category of practically uncontaminated. The $\mathrm{Cd} I_{\text {geo }}$ values varied highly, ranging from 0.31 to 1.44 . The median $I_{\text {geo }}$ for $\mathrm{Cd}$ was 0.91 , which is considered uncontaminated to moderately contaminated.

The correlation analysis of heavy metals for Part I and Part II is listed separately in Table 10 . The results showed that all heavy metal elements were highly correlated with each other, indicating that these heavy metals have similar sources. Beside,

Table 8 : Calculation of Pollution Index (PI) and Nemero Synthesis Index (NSI)

\begin{tabular}{lllllllll}
\hline & & Cu & Zn & Pb & Cd & Cr & As & NSI \\
\hline Part I & Max & 76.33 & 47.36 & 31.53 & 100.98 & 7.35 & 21.13 & 78.21 \\
& Min & 15.89 & 24.30 & 16.44 & 28.99 & 3.34 & 4.60 & 28.63 \\
& Mean & 55.73 & 38.66 & 26.02 & 59.87 & 5.77 & 13.57 & 51.53 \\
Part II & Max & 23.15 & 39.61 & 25.30 & 50.00 & 7.53 & 6.85 & 38.81 \\
& Min & 8.84 & 14.52 & 9.28 & 11.75 & 2.14 & 2.54 & 14.07 \\
& Mean & 14.44 & 24.86 & 15.55 & 25.24 & 4.49 & 4.17 & 23.15 \\
Part III & Max & 1.05 & 1.05 & 0.82 & 4.08 & 1.37 & 1.36 & 3.09 \\
& Min & 0.65 & 0.91 & 0.66 & 1.86 & 1.09 & 0.58 & 1.57 \\
& Mean & 0.89 & 0.99 & 0.75 & 2.91 & 1.24 & 1.03 & 2.26 \\
\hline
\end{tabular}

Table 9 : Geoaccumulation Index $\left(I_{g e 0}\right)$ of heavy metals in sediments

\begin{tabular}{llllllll}
\hline & & Cu & Zn & Pb & Cd & Cr \\
\hline Part I & Max & 5.67 & 4.98 & 4.39 & 6.07 & 2.29 & 3.82 \\
& Min & 3.41 & 4.02 & 3.45 & 4.27 & 1.15 & 1.62 \\
& Mean & 5.10 & 4.66 & 4.08 & 5.22 & 1.90 & 3.02 \\
\multirow{4}{*}{ Part II } & Max & 3.95 & 4.72 & 4.08 & 5.06 & 2.33 & 2.19 \\
& Min & 2.56 & 3.27 & 2.63 & 2.97 & 0.51 & 1.48 \\
& Mean & 3.20 & 3.99 & 3.30 & 3.92 & -0.13 & -0.13 \\
& Max & -0.51 & -0.52 & -0.87 & 1.44 & -0.46 & -1.36 \\
& Min & -1.20 & -0.72 & -1.19 & 0.31 & -0.28 & -0.60 \\
\hline
\end{tabular}


Table 10 : Statistical results of principal components analysis

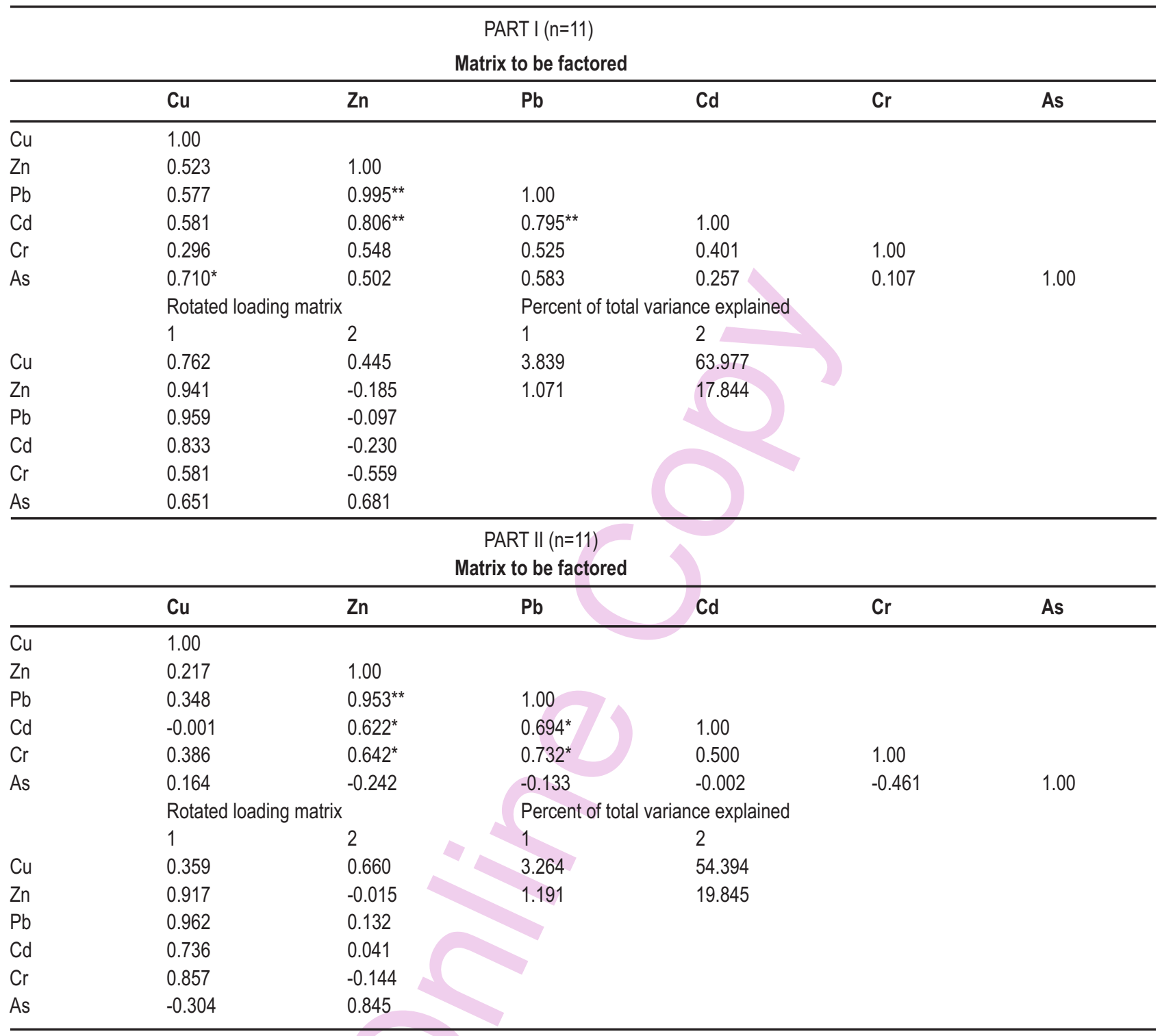

Significant values $(p<0.05)$ are marked with an asterisk $\left({ }^{*}\right)$; Significant values $(p<0.01)$ are marked with double asterisks $\left(^{* *}\right)$

great spatial variability also indicates that these pollutants may come from anthropogenic sources that are the results of mine factories and industries. Principal component analysis (PCA) was calculated on the heavy metals concentrations to identify the potential sources and associations among these variables. The first two factors with eigenvalues greater than 1.0 in Part I and Part II account for $81.82 \%$ and $74.24 \%$, respectively, of total variance. Individually, factor 1 in Part I, accounted for $63.97 \%$, was characterized by almost all heavy metals, while Factor 2, accounted for $17.84 \%$, was mainly dominated by As and $\mathrm{Cu}$. This means that the heavy metals are dominated by mixed factors. Based on the PCA, factor 1 can be identified as industrial sources because it consists primarily of all types of heavy metals and factor 2 can be identified as soil erosion and agricultural activities (Huang et al., 2009). Similar result can also be concluded for Part II. In these areas, factor 1 was dominated by high loadings of $\mathrm{Pb}$, $\mathrm{Zn}, \mathrm{Cd}$, and $\mathrm{Cr}$ and a low loading of $\mathrm{Cu}$, which usually results from the mine extracts and purification of non ferrous metals. Association between $\mathrm{Cu}$ and As can be observed in factor 2, which accounts for $19.84 \%$ of total variance. The primary emission source for this factor is resuspension of soil-derived particles. Accordingly, these results suggest that the concentrations of $\mathrm{Cu}$ in sediments originate from two types of emission sources. Apart from the influence of a nonferrous mine, $\mathrm{Cu}$ partly originates from soil surface erosion and agricultural areas (Bem etal., 2003). 
This study revealed that the paddy fields planted along the Le'An River in Lake Poyang were facing different degree heavy metals pollution which was mostly decided by the elevation where the farmlands were cultivated. A higher ecological risk was also observed for the higher ratio of exchangeable status of heavy metals. Nonferrous metal mining and processing enterprises may have contributed to contamination enrichment and magnification. In addition, hydrological processes in the main stream could also affect the spatial distribution of pollutants in the research areas.

\section{Acknowledgments}

This study was supported by National Natural Science Foundation of China (51369024; 51469017; 51579127), Ministry of Water Resources (201401039), Project of Jiangxi Provincial Technology Department (20142BBF60012; 20142BAB213024), Open Research Fund Program of Key Laboratory of Water Science and Engineering, Nanjing Hydraulic Research Institute (Yk914014) and Open Research Fund Program of Water Resource and Eco-system Environmental Research Center for Poyang Lake, Ministry of Water Resources (KFJJ201401).

\section{References}

Adamo, P., M. Arienzo, M. Imperato, D. Naimo, G. Nardi and D. Stanzione: Distribution and partition of heavy metals in surface and sub-surface sediments of Naples city port. Chemosphere, $\mathbf{6 1}$, 800-809(2005).

Ajasa, A.M.O., M.O. Bello, A.O. Ibrahim, I.A. Ogunwande and N.O. Olawore: Heavy trace metals and macronutrients status in herbal plants of Nigeria. Food Chem., 85, 67-71(2004).

Alfaraas, A.M.J., J. Khairiah, B.S. Ismail and T. Noraini: Effects of heavy metal exposure on the morphological and microscopical characteristics of paddy plant. J. Environ. Biol., 37, 955-963 (2016).

Arora, M., B. Kiran, S. Rani, A. Rani, B. Kaur and N. Mittal: Heavy metal accumulation in vegetables irrigated with water from different sources. Food Chem., 111, 811-815(2008).

Bai, J., B. Cui, B. Chen, K. Zhang, W. Deng, H. Gao and R. Xiao: Spatial distribution and ecological risk assessment of heavy metals in surface sediments from a typical plateau lake wetland, China. Ecol. Model., 222, 301-306 (2011).

Bem, H., M. Gallorini, E. Rizzio and M. Krzemińska: Comparative studies on the concentrations of some elements in the urban air particulate matter in Lodz City of Poland and in Milan, Italy. Environ. Int., 29, 423-428 (2003).

Borrego, J., J. Morales, M. De la Torre and J. Grande: Geochemical characteristics of heavy metal pollution in surface sediments of the Tinto and Odiel river estuary (southwestern Spain). Environ. Geol., 41, 785-796 (2002).

Burton, Jr., G. A. : Sediment quality criteria in use around the world. Limnol., 3, 65-76 (2002).

Chander, K., J. Dyckmans, R. Joergensen, B. Meyer and M. Raubuch: Different sources of heavy metals and their long-term effects on soil microbial properties. Biol. Fertil. Soils, 34, 241-247 (2001).

Christophoridis, C., D. Dedepsidis and K. Fytianos: Occurrence and distribution of selected heavy metals in the surface sediments of Thermaikos Gulf, N. Greece. Assessment using pollution indicators. J. Hazard. Mater., 168, 1082-1091 (2009).

Deng, H., Z. H. Ye and M. H. Wong : Accumulation of lead, zinc, copper and cadmium by 12 wetland plant species thriving in metalcontaminated sites in China. Environ. Pollut., 132, 29-40 (2004).

Facchinelli, A., E. Sacchi and L. Mallen: Multivariate statistical and GISbased approach to identify heavy metal sources in soils. Environ. Pollut., 114, 313-324 (2001).

Gong, X. F., C. L. Chen, W. B. Zhou, M. F. Jian and Z. H. Zhang: Assessment on heavy metal pollution in the sediment of Poyang Lake. Environ. Sci., 27, 732-736 (in Chinese, 2006).

He, M., Z. Wang and H. Tang: Spatial and temporal patterns of acidity and heavy metals in predicting the potential for ecological impact on the Le An river polluted by acid mine drainage. Sci. Total Environ., 206, 67-77 (1997).

$\mathrm{He}, \mathrm{M}$., Z. Wang and H. Tang: The chemical, toxicological and ecological studies in assessing the heavy metal pollution in Le An River, China. WaterRes., 32, 510-518 (1998).

Huang, S., J. Tu, H. Liu, M. Hua, Q. Liao, J. Feng and G. Huang: Multivariate analysis of trace element concentrations in atmospheric deposition in the Yangtze River Delta, East China. Atmos. Environ., 43, 5781-5790 (2009).

Ji, Y., J. Zhang, R. Li, B. Pan, L. Zhang and X. Chen: Distribution and partitioning of heavy metals in sediments of the Xinjiang River in Poyang Lake Region, China. Environ. Prog. Sustain., 34, 713-723 (2015).

Ji, Y., J. Zhang, X. Huang, C. Bai and X. Chen: Investigation and assessment of heavy metals in surface sediments of Ganjiang River, China. J. Environ. Biol., 35, 1173-1179 (2014).

Kokovides, K., M. Loizidou, K. J. Haralambous and T. Moropoulou: Environmental study of the marinas Part I. A study on the pollution in the marinas area. Environ. Technol., 13, 239-244 (1992).

Li, M., S. Zang, H. Xiao and C. Wu: Speciation and distribution characteristics of heavy metals and pollution assessments in the sediments of Nashina Lake, Heilongjiang, China. Ecotoxicology, 23, 681-688 (2014).

Li, M., J. C. Wu, X. L. Zhang and X. J. Zou: Assessment on heavy metal pollution at five estuaries of Poyang Lake. J. Nanchang Univer., 32, 483-486 (in Chinese, 2008).

Liu, W., Z. Wang, X. Wen and H. Tang: The application of preliminary sediment quality criteria to metal contamination in the Le An River. Environ. Pollut., 105, 355-366 (1999).

Liu, F. W., W. Yan, W. Z. Wang, S. C. Guo and Z. Chen: Pollution of heavy metals in the Pearl River Estuary and its assessment of potential ecological risk. Mar. Environ. Sci., 21, 34-38 (2002, in Chinese).

Luo, M., J. Li, W. Cao and M. Wang: Study of heavy metal speciation in branch sediments of Poyang Lake. J. Environ. Sci., 20, 161-166 (2008).

Muchuweti, M., J. W. Birkett, E. Chinyanga, R. Zvauya, M. D. Scrimshaw and J. N. Lester: Heavy metal content of vegetables irrigated with mixtures of wastewater and sewage sludge in Zimbabwe: implications for human health. Agric., Ecosyst. Environ., 112, 41$48(2006)$.

Naimo, T. J.: A review of the effects of heavy metals on freshwater mussels. Ecotoxicology, 4, 341-362(1995).

Ni, S., R. Li and A. Wang: Heavy metal content in scalp hair of the inhabitants near Dexing Copper Mine, Jiangxi Province, China. Sci. China Earth Sci., 54, 780-788 (2011).

Razo, I., L. Carrizales, J. Castro, F. Díaz-Barriga and M. Monroy: Arsenic and heavy metal pollution of soil, water and sediments in a semiarid climate mining area in Mexico. Water, Air, Soil Pollut., 152, 129-152 (2004).

Sundaray, S. K., B. B. Nayak, S. Lin and D. Bhatta: Geochemical speciation and risk assessment of heavy metals in the river estuarine sediments-a case study : Mahanadi basin, India. J. Hazard. Mater., 186, 1837-1846(2011). 
Tessier, A., P. G. Campbell and M. Bisson: Sequential extraction procedure for the speciation of particulate trace metals. Anal. chem., 51, 844-851 (1979).

Waykar, B. And R. Petare: Studies on monitoring the heavy metal contents in water, sediment and snail species in Latipada reservoir. J. Environ. Biol., 37, 585-589 (2016).

Woitke, P., J. Wellmitz, D. Helm, P. Kube, P. Lepom and P. Litheraty : Analysis and assessment of heavy metal pollution in suspended solids and sediments of the river Danube. Chemosphere, 51, 633642 (2003).

Xin, K., X. Huang, J. Hu, C. Li, X. Yang and S. K. Arndt: Land use change impacts on heavy metal sedimentation in mangrove wetlands -A case study in Dongzhai Harbor of Hainan, China. Wetlands, 34, 1-8 (2014).

Yi, Y., Z. Yang and S. Zhang: Ecological risk assessment of heavy metals in sediment and human health risk assessment of heavy metals in fishes in the middle and lower reaches of the Yangtze River basin. Environ. Pollut., 159, 2575-2585 (2011).

Yuan, G. L., C. Liu, L. Chen and Z. Yang: Inputting history of heavy metals into the inland lake recorded in sediment profiles: Poyang Lake in China. J. Hazard. Mater., 185, 336-345 (2011).

Zeng, F. P., C. Xin, H. Y. Xiao and W. B. Zhou: Distribution and fractions of heavy metals in Poyang Lake at inlet of Raohe River. Environ. Monit. Administ. Technol., 23, 19-22 (in Chinese, 2011).

Zhang, W., H. Feng, J. Chang, J. Qu, H. Xie and L. Yu: Heavy metal contamination in surface sediments of Yangtze River intertidal zone: An assessment from different indexes. Environ. Pollut., 157, 1533-1543 (2009).

Zhuang, P., M. B. McBride, H. Xia, N. Li and Z. Li: Health risk from heavy metals via consumption of food crops in the vicinity of Dabaoshan mine, South China. Sci. Total Environ., 407, 1551-1561 (2009). 